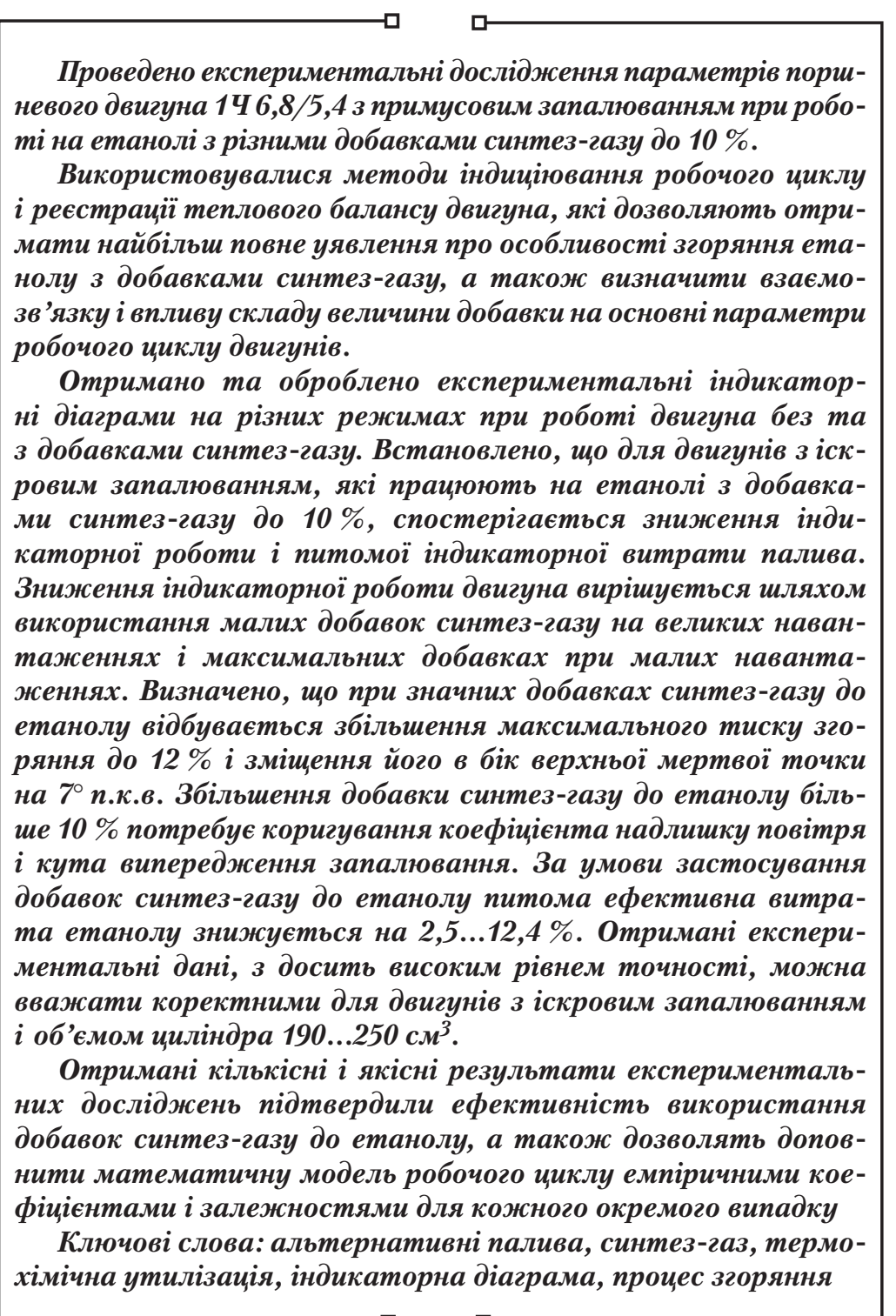

UDC 621.438

DOI: $10.15587 / 1729-4061.2018 .136380$

\section{ANALYSIS OF THE PISTON ENGINE OPERATION ON ETHANOL WITH THE SYNTHESIS- GAS ADDITIVES}

O. Mytrof a nov

PhD, Associate Professor*

E-mail: oleksandr.mytrofanov@nuos.edu.ua

A. Proskurin

$\mathrm{PhD*}$

E-mail: arkadii.proskurin@nuos.edu.ua

A. Poznansky i

$\mathrm{PhD}$

Department of engineering mechanics and technology of machine building ** E-mail: andreypoznansky@gmail.com

*Department of internal combustion engines, plants and technical operation**

**Admiral Makarov National

University of Shipbuilding

Heroiv Ukrainy ave., 9, Mykolaiv, Ukraine, 54025

\section{Introduction}

Today and over the coming decades, promising types of engines for small and medium-sized transport installations are considered to be the diesel engines and the forced spark ignition engines. Operation of such vehicles leads to air pollution, as well as increases the greenhouse gases in the world. Given this, the main task in the development of transport energy engineering appears to be ensuring efficient operation of engines that use alternative fuel [1-4].

The transportation engines could utilize as an alternative fuel ethyl and methyl alcohols, vegetable oils, hydrogen, biodiesel, liquefied or compressed natural gas, the synthesis gas.

Application of alcohols, particularly ethanol, in transport energy engineering is of interest since it is an alternative to fossil fuels for internal combustion engines [5]. Ethanol is a renewable fuel, which is typically obtained by fermenting the agricultural biomass, the waste of wood, sugar, food industries.

The fuel used directly determines the environmental level of engines, that is, the degree of negative effect on the environment: flora and fauna, humans, architectural structures. In addition to standard harmful components in the exhaust gases from engines operated on fossil fuels, there is a group of components related to greenhouse gases. The greenhouse gases include water vapor, methane, CFCs, carbon dioxide $\mathrm{CO}_{2}$ and some other compounds. Increasing the amount of carbon dioxide leads to an increase in the so-called greenhouse effect, which may affect a climate change on our planet. In contrast to fossil fuels, the carbon dioxide released during ethanol combustion does not increase the greenhouse gas emissions. The carbon atoms, obtained during ethanol combustion, represent the atmospheric carbon dioxide, restored by plants, from which ethanol was obtained (a reversible process). 


\section{Literature review and problem statement}

Ethanol has several advantages for transportation ICE: it is less toxic than gasoline, easily biodegradable, it is a renewable fuel, and improves environmental performance of the engine [6]. However, despite significant benefits, ethanol has its drawbacks, which hinder its widespread use in piston engines. The main disadvantages are associated with differences from petroleum fuels in terms of physical-chemical properties, which makes it necessary to introduce significant structural changes to the engine design. Thus, paper [7] discovered that the application of benzoethanol mixtures with large concentrations of ethanol as fuel in gasoline engines is preceded by a serious structural refinement of ICE systems, namely the use of a variable valve timing mechanism, employment of starting preheaters, change in compression ratio, improvement of exhaust system.

One of the problems when using ethanol is the start of the cold engine. At a low temperature of the fuel, there is insufficient evaporation to form a combustible mixture, which makes it difficult to start the engine at an ambient temperature below $+15{ }^{\circ} \mathrm{C}$. In the United States, this problem is addressed by introducing additives of gasoline to ethanol (15\% of gasoline in a blend), which contributes to the combustion of ethanol at a low temperature of the environment.

The lowest calorific value of methanol is $15.9 \mathrm{~mJ} / \mathrm{l}$; ethanol $-21.3 \mathrm{~mJ} / \mathrm{l}$, which is significantly less than that of conventional gasoline $(32 \mathrm{~mJ} / \mathrm{l})$. In order to achieve similar thermal efficiency in the use of alcohol fuel, it is necessary to increase its consumption. Ethanol is also capable of absorbing water. Paper [8] investigated in detail significant corrosive effect of an alcohol fuel on the fuel system. One of the promising techniques that eliminate most of the disadvantages of ethanol application in ICE is to use it in the form of the synthesis-gas, obtained by thermochemical conversion. The synthesis-gas is a mixture of flammable gases whose main components are $\mathrm{CO}, \mathrm{H}_{2}, \mathrm{CH}_{4}, \mathrm{C}_{2} \mathrm{H}_{4}, \mathrm{C}_{2} \mathrm{H}_{6}$. A significant disadvantage, limiting the widespread use of the synthesis-gas as an independent fuel for ICE, is a lower specific heat of combustion $(25 \ldots 30 \mathrm{~mJ} / \mathrm{kg})$ compared to traditional fuels, resulting in reduced engine power. A possible way to deal with the problem related to the loss of power when the engine is fueled by the synthesis-gas is to use the synthesis-gas as an additive to primary fuel at partial loads.

Paper [9] describes in detail the process of combustion of diesel fuel with micro additives of the synthesis-gas; there is, however, no analysis of the impact of additives on the indicator and effective performance indices of the engine. Study [10] investigated engine operation on the synthesis-gas, obtained by the conversion of methanol. The authors built experimental indicator diagrams and gave characteristics of heat release at combustion. However, there is no analysis of change in the power of engine performance when using the synthesis-gas. Papers [11, 12] focused on studying the change in the environmental parameters of the engine; in this case, a change in the parameters of the working cycle and their impact on effective indicators have not been explored.

An analysis of the scientific literature revealed that considerable attention has been paid to experimental investigations of the influence of synthesis-gas on the organization of ICE operating process. We, however, could not find sufficient and reliable experimental and theoretical data on peculiarities in the organization of a working cycle of engines operating on ethanol with additives of the synthesis-gas. In addition, the processes that occur in ICE at combustion, as well as the relationship and influence of the amount of additive of the synthesis-gas on the main parameters of engines working cycle, have remained insufficiently examined.

\section{The aim and objectives of the study}

The aim of this work is to study operating parameters of the spark-ignition engine, as well as patterns in the combustion process when using the additives of synthesis-gas to ethanol.

To accomplish the aim, the following tasks have been set:

- to design an experimental bench and a system of measurements;

- to build reliable indicator diagrams for the piston engine operated on ethanol with various additives of the synthesis-gas;

- to process the indicator diagrams, as well as the results of direct measurements, to determine the effect of additives of the synthesis- gas to ethanol on engine performance.

\section{Description of the bench and the procedure for} conducting experimental study into engine parameters

The actual processes of ICE working cycle, especially the combustion process, depend on many factors in the chemical kinetics of fuel burning, thermodynamics and gas dynamics, heat and mass transfer, and many others. Especially complicated is the process of combustion of the synthesis-gas, primarily due to the presence of many components in the composition, which, in turn, affect the process in a different way.

It is not always possible, by using mathematical modeling based on classical differential equations, to describe actual processes occurring in the working cylinder, elements of the exhaust gas tract, and a power plant in general. Therefore, mathematical models require the application of certain assumptions, empirical equations and constants, derived experimentally. Experimental method makes it possible to validate the assumptions adopted, to complement a mathematical model with empirical coefficients and dependences for each particular case, as well as to confirm the adequacy of the model in general and to define the limits of its application.

To conduct experimental study into the working cycle of ICE operated on ethanol with additives of the synthesis-gas, we designed a bench based on the engine with external mixture formation 1Ch 6.8/5.4 (Fig. 1). This is a four-stroke petrol engine, which runs on a generator of electric current. The engine 1Ch 6.8/5.4 can operate both on pure ethanol and a mixture of ethanol and the gaseous synthesis-gas, obtained from the thermochemical disposal of flue gas heat. Depending on engine load and the amount of utilized heat of exhaust gases, an additive of the synthesis gas to ethanol may vary.

The engine $1 \mathrm{Ch} 6.8 / 5.4$ is loaded by a regular AC generator. The resulting electrical power arrives to the unit of heaters through a load control system. Value of voltage is determined using a voltmeter. The experimental bench is equipped with the following instruments: a tachometer to determine the number of revolutions of the engine crankshaft, instruments to measure the temperature of exhaust gases in cylinders. To determine the air flow rate through the engine, the gas meter RG-40 is mounted at the inlet. 


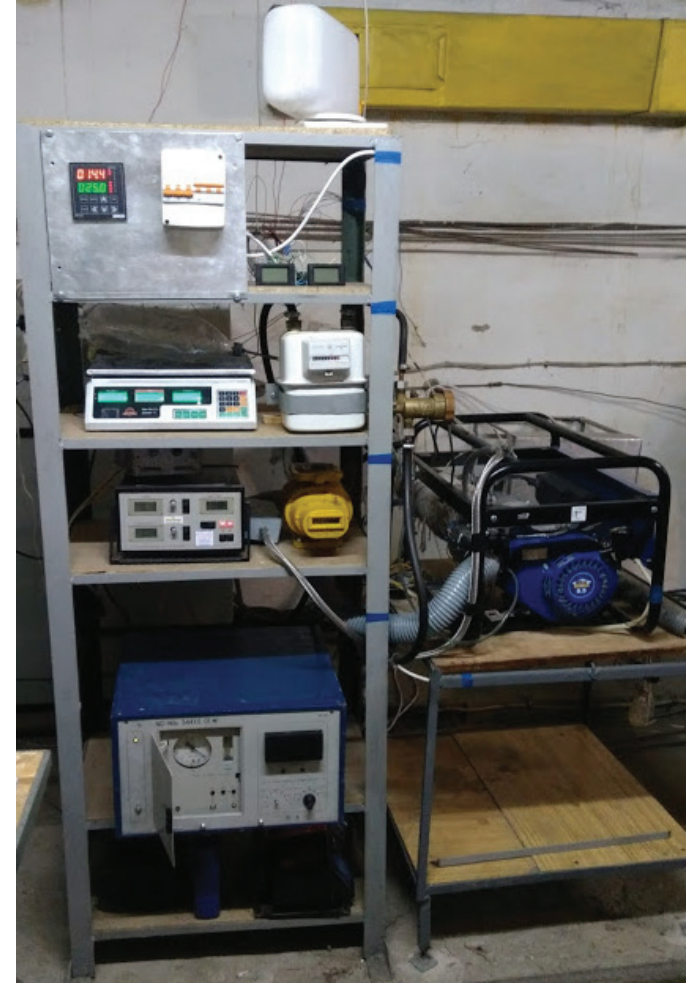

Fig. 1. General view of experimental bench based on the engine with spark ignition $1 \mathrm{Ch} 6.8 / 5.4$

To acquire the indicator diagrams from the engine $1 \mathrm{Ch} 6.8 / 5.4$, we used the specialized dynamic pressure transducer of continuous action Kistler 7613C. It does not require additional cooling and can be applied at a temperature of $350{ }^{\circ} \mathrm{C}$. In order to obtain reliable indicator diagrams, the sensitive element of the sensor (Fig. 2) was placed as close as possible to the combustion chamber; in this case, the compression ratio did not change. The pressure sensor was screwed into the engine head via a bronze reducer (Fig. 3).

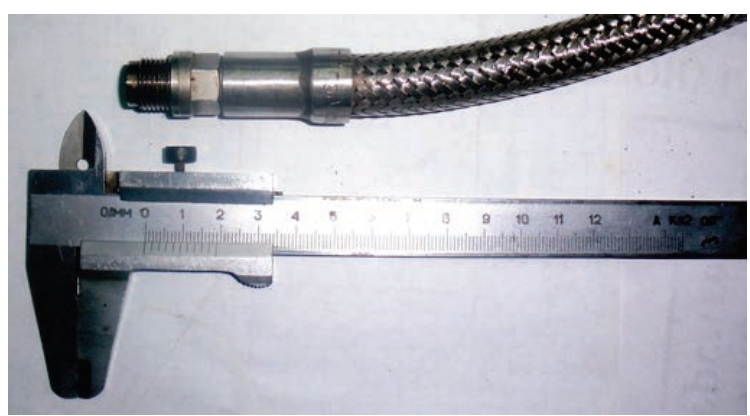

Fig. 2. Sensitive element of the pressure sensor Kistler $7613 \mathrm{C}$

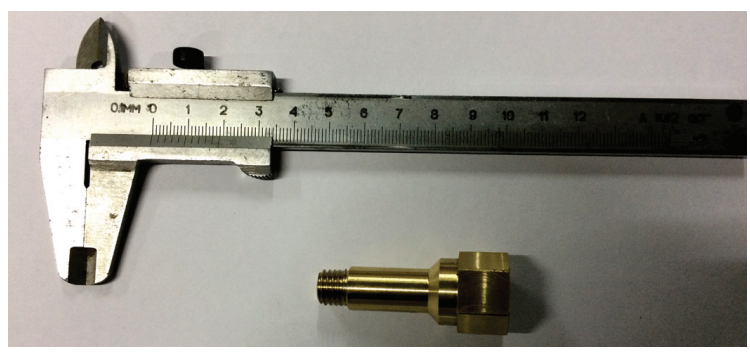

Fig. 3. Bronze reducer
Fig. 4 shows images of the cylinder head assembly with the pressure sensor Kistler 7613C.
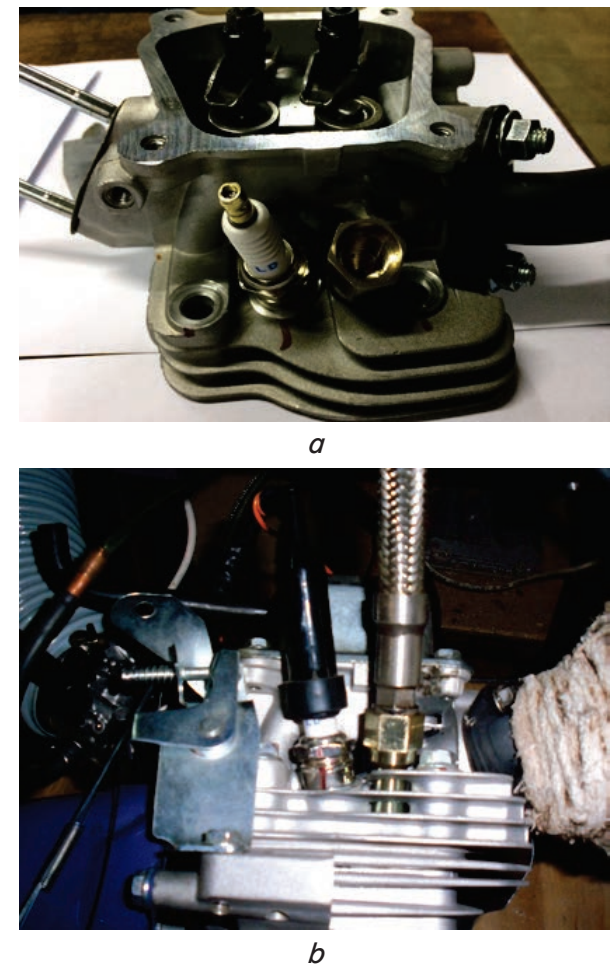

Fig. 4. Cylinder head assembly with the pressure sensors Kistler 7613C: $a$ - general view of the working cylinder cap with a reducer; $b$ - pressure transducer Kistler in the assembly with engine

Results of measurements of the indicator pressure were transmitted to the data processing microprocessor with a galvanic isolation of type AI8S-5A to be processed using the FASTWELL software and recorded into a PC.

Experiments were performed at an ambient temperature of $298 \mathrm{~K}$, atmospheric pressure $101 \mathrm{kPa}$, using the petrol AI-95 according to GOST 4840-2007 (complies with the European standard EN 228-2004), using ethanol according to GOST 4221-2003, and the synthesis-gas (\% content by volume: $\mathrm{CO}=34 \%, \mathrm{H}_{2}=43 \%, \mathrm{CH}_{4}=23 \%$ ). The estimated lowest specific calorific value of synthesis-gas combustion is $28.79 \mathrm{~mJ} / \mathrm{kg}$. The values for parameters of the environment and the synthesis-gas composition were constant during study.

\section{Results of experimental study into engine parameters operated on ethanol with additives of the synthesis-gas}

Results of experimental study into parameters of the engine 1Ch 6.8/5.4 operated on ethanol are shown in Fig. 5 in the form of a fragment of the consistently measured indicator diagrams. These diagrams quite clearly demonstrate stability of the engine operation under mode and their quality. Fig. 6 show the processed (expanded and collapsed) indicator diagrams for different modes of engine operation. In this case, the ignition advance angle $\Theta=20^{\circ}$ c.s.r., excess air coefficient $\alpha=0.98 \ldots 1.04$, and the engine crankshaft rotation speed $n=3,000 \mathrm{rpm}$. 


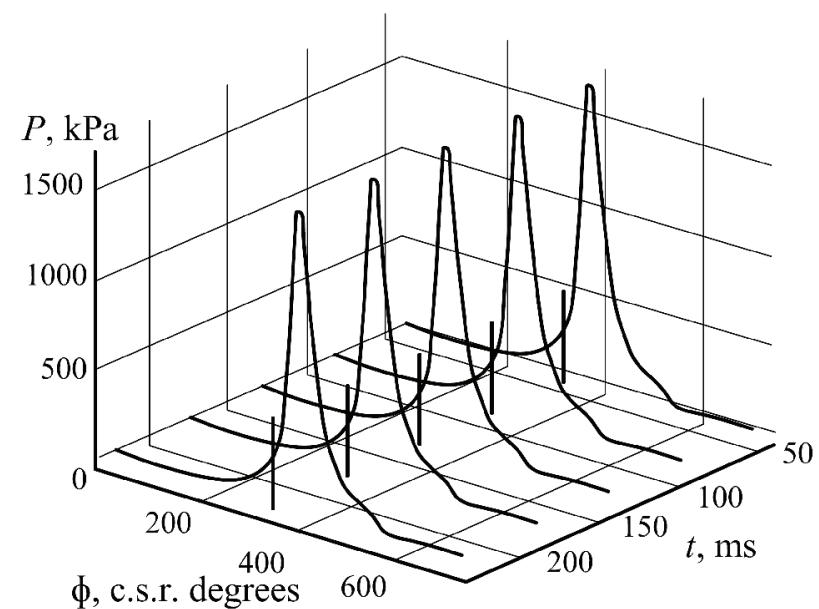

Fig. 5. Fragment of consecutive indicator diagrams when operated on ethanol

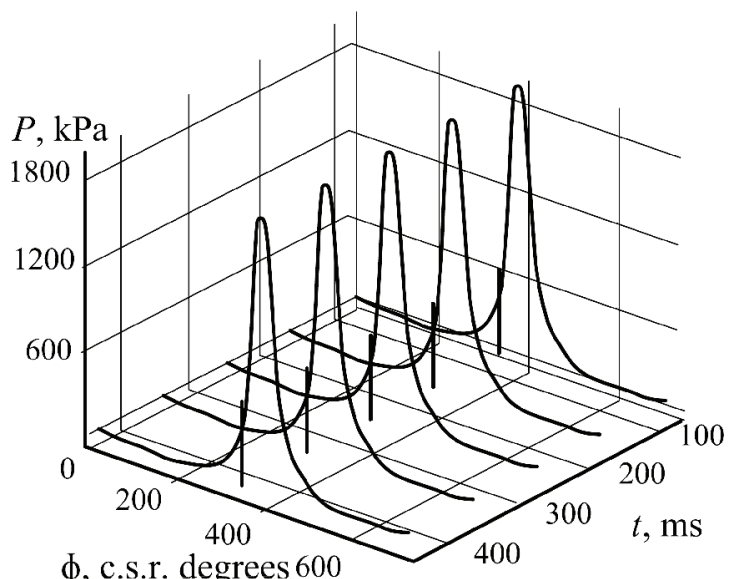

Fig. 7. Fragment of the series of consecutive indicator diagrams when operated on ethanol with additives of the synthesis-gas
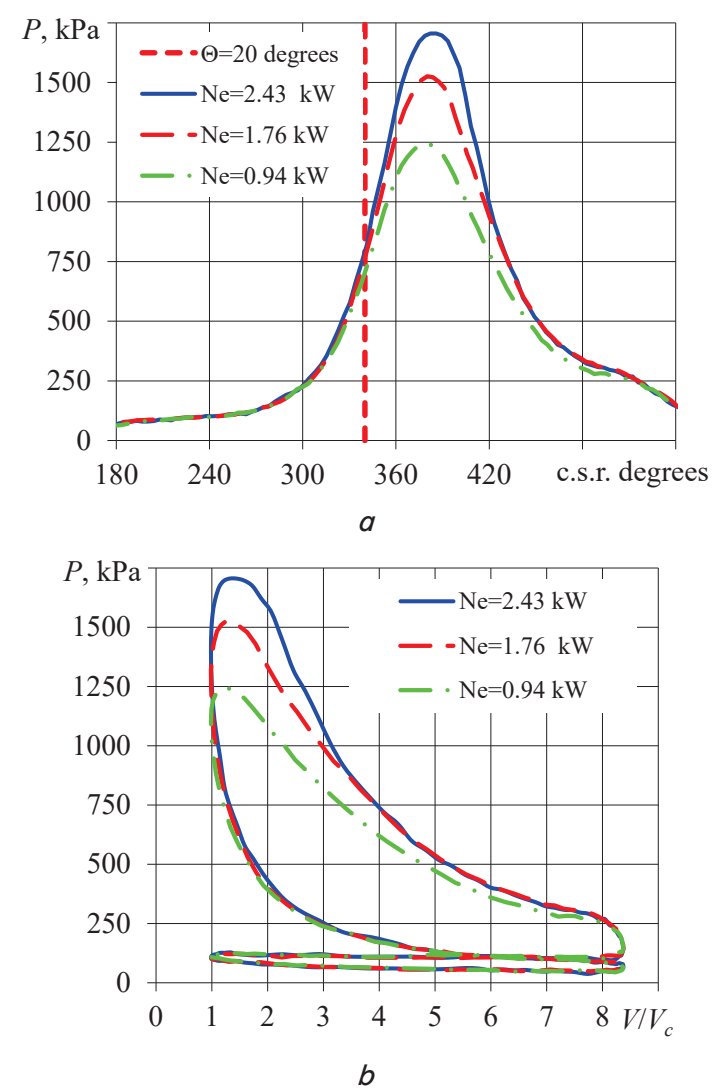

Fig. 6. Experimental indicator diagrams when operated on ethanol: $a$ - expanded; $b$ - collapsed

Results of experimental study into engine operation on ethanol with additives of the synthesis-gas in the amount of $2.1 \ldots 6.5 \%$ by weight are shown in Fig. 7 in the form of a fragment of the consistently measured indicator diagrams.

Fig. 8 show the processed (expanded and collapsed) indicator diagrams for various operation modes. In this case, the ignition advance angle $\Theta=20^{\circ}$ c.s.r., excess air coefficient $\alpha=1.05 \ldots 1.18$, the engine crankshaft rotation speed $n=3,000 \mathrm{rpm}$.
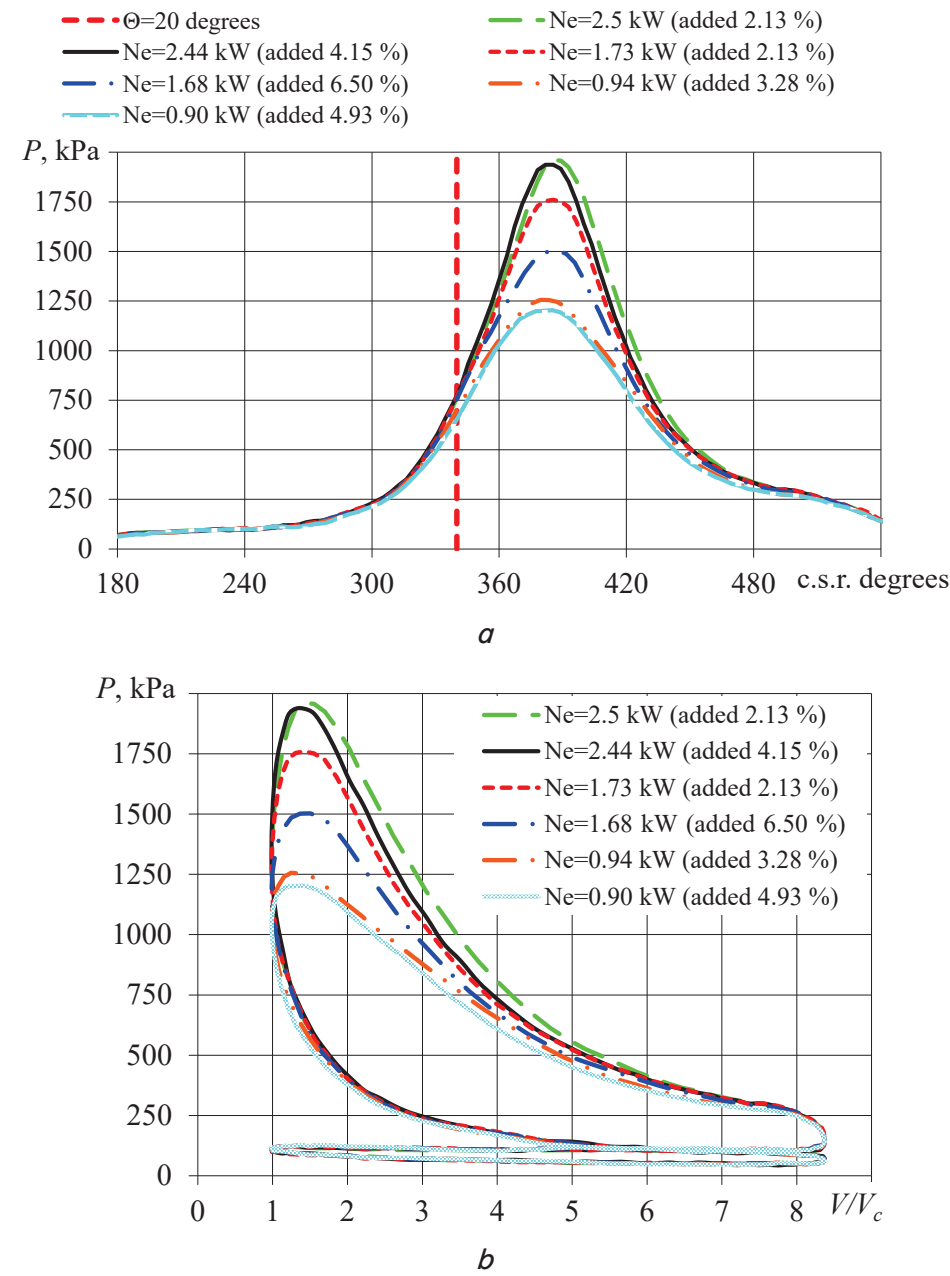

Fig. 8. Experimental indicator diagrams when the engine is operated on ethanol with the synthesis-gas additives in the amount of $2.1 \ldots 6.5 \%$ by weight: $a$ - expanded; $b$-collapsed

Engine performance indicators are divided into indicator (internal) and effective (external) ones.

Indicator indices characterize the perfection of the work cycle and take into consideration only the thermal losses in the cylinder. 
Effective indicators, in addition to thermal losses, account for the mechanical losses that form when the energy of gases expansion is transferred through the piston and crank mechanism to the engine crankshaft. Processing the indicator diagrams, shown in Fig. 8, will make it possible to acquire data on the progress of ICE working process and its main indicators.

\section{Discussion of results of studying the influence of additives of the synthesis-gas on engine operating parameters}

An analysis of indicator diagrams revealed that the presence of the synthesis gas in a fuel/air mixture leads to an increase in the maximum combustion pressure by $12 \%$ and shifts it toward the upper dead point (UDP) by $7^{\circ}$ of crankshaft rotation. These factors did not lead to the more rigid engine operation because the dynamic loads on the parts of the crank mechanism are not exceeded. A further increase in the amount of additive of the synthesis gas to ethanol (larger than $10 \%$ ) without the adjustment of excess air coefficient upwards and the ignition advance angle downwards might adversely affect engine operation.

Processing the indicator diagrams allowed us to derive dependences of change in the indicator indices of engine operation cycle (specific fuel consumption, efficiency coefficient, mean pressure, cycle work) on an additive of the synthesis-gas (Fig. 9). An increase in the amount of additive of the synthesis-gas leads to an increase in the indicator efficiency coefficient and to a decrease in fuel consumption.

Fig. 10 shows dependences of change in the specific effective ethanol consumption under various operating modes depending on an additive of the synthesis-gas. The large content of hydrogen in the synthesis-gas composition significantly improves the combustion process that is clearly represented by the increased indicator engine efficiency and by the reduced specific fuel consumption. Depending on the amount of additive of the synthesis-gas, a reduction in the specific effective fuel consumption occurs under all operating modes and equals $2.5 \ldots 12.4 \%$. The improved engine efficiency is also affected by the expansion of ignition limits for a fuel/air mixture. An increase in the cycle efficiency coefficient with the increase in $\alpha$ is associated primarily with the reduction of heat capacity and heat content of combustion products, which in turn reduces the proportion of thermodynamic losses.
The obtained experimental data make it possible to identify a number of equally important indicators that characterize separate stages in a working process. Thus, by the in-depth exploration of the operating cycle in terms of processes, one can define filling ratios $\eta_{v}$ and residual gases $\gamma_{r}$, the mean pressure at pumping moves $p_{p m}$, indicators of compression polytrope $n_{1}$ and expansion polytrope $n_{2}$ and so on.$$
g_{i}
$$
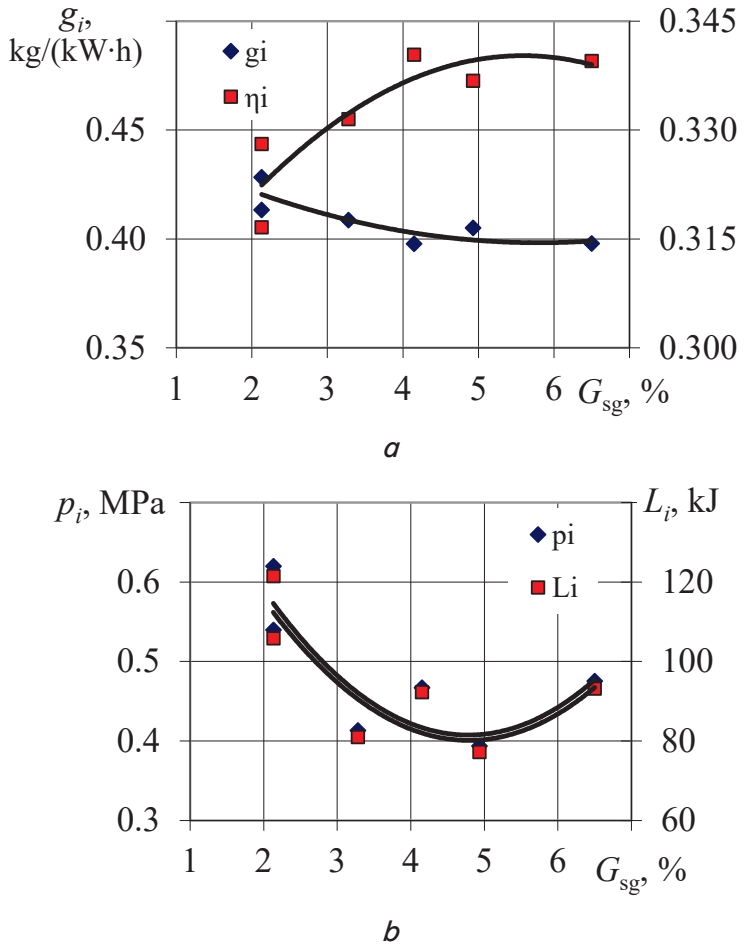

Fig. 9. Indicator indices of the engine $1 \mathrm{Ch} 6.8 / 5.4$ operated on ethanol with the synthesis-gas additives $G_{\text {sg }}$ :

$a$ - indicator fuel consumption $g_{i}$ and indicator efficiency coefficient $\eta_{i} ; b$ - average indicator pressure $p_{i}$ and indicator cycle work $L_{i}$

The obtained experimental data can be considered with a sufficiently high degree of accuracy to be correct for engines with spark ignition and a cylinder volume of $190 \ldots 250 \mathrm{~cm}^{3}$. As evidenced by common practice, application of the results obtained for engines with a high volume of cylinder is feasible, but it would be promising to conduct such studies into engines with a higher volume of cylinder.

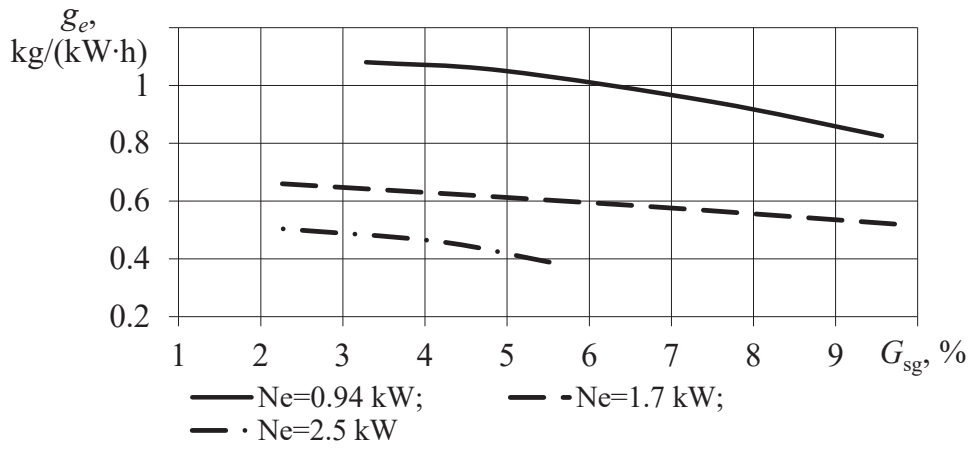

Fig. 10. Change in the specific effective ethanol consumption $g_{e}$ under different modes of engine operation depending on an additive of the synthesis-gas $G_{\text {sg }}$ 
Experimental studies were carried out using the engine with external mixture formation, which in turn led to some reduction in the effective engine power. That, however, can be resolved quite simply in the longer term by the application of internal carburetion (injection of the compressed synthesis-gas into the engine cylinder at closed intake and exhaust valves). The effective engine performance indicators are also significantly impacted by the ignition advance angle, compression degree, excess air ratio, camshaft phases. Studying the effect of the specified parameters on engine operation looks promising; the results could significantly complement the already obtained results.

\section{Conclusions}

1. The experimental installation and a measuring system based on the engine 1Ch 6.8/5.4 have allowed us to identify changes in the basic parameters of the engine operated on ethanol with additives of the synthesis gas in terms of a loading characteristic. We also acquired the indicator diagrams of engine operation at a different amount of an additive of the synthesis-gas to ethanol.

2. It was established that the engines with spark-ignition operated on ethanol with additives of the synthetic gas in the amount to $10 \%$ demonstrate a decrease in the indicator work; in this case, there is also a drop in the specific indicator fuel consumption. A decrease in the indicator engine performance can be resolved by varying the synthesis-gas feed under different modes, namely small amounts of additive of the synthesis-gas for heavy loads, and maximal amounts at low loads.

3. A significant amount of the synthesis-gas additive to ethanol results in an increase in the maximum pressure of combustion by $12 \%$ and its shift towards the upper dead point at $7^{\circ}$ c.s.r. In this case, the coefficient of excess air is $1.05 \ldots 1.18$. Increasing the additive of the synthesis-gas to ethanol by larger than $10 \%$ requires adjustments of excess air ratio and the ignition advance angle. When using the synthesis-gas additives to ethanol, the ethanol specific effective consumption reduces by $2.5 . . .12 .4 \%$.

\section{References}

1. Levterov A. M., Levterova L. I., Gladkova N. Yu. Ispol'zovanie al'ternativnyh topliv v transportnyh DVS // Avtomobil'niy transport. 2010. Issue 27. P. 61-64.

2. Kuleshko Ya. Ya. Neobhodimost' ispol'zovaniya al'ternativnyh vidov topliva dlya avtotransporta // Molodezh' i nauka: sbornik materialov IX Vserossiyskoy nauchno-tekhnicheskoy konferencii studentov, aspirantov i molodyh uchenyh s mezhdunarodnym uchastiem, posvyashchennoy 385-letiyu so dnya osnovaniya g. Krasnoyarska. Krasnoyarsk: Sibirskiy federal'nyy un-t, 2013. URL: http://conf.sfu-kras.ru/sites/mn2013/section076.html

3. Mysnik M. I., Svistula A. E. Analiz teplofizicheskih svoystv al'ternativnyh topliv dlya dvigateley vnutrennego sgoraniya // Polzunovskiy vestnik. 2009. Issue 1-2. P. 37-43.

4. Danilov A. M., Kaminskiy E. F., Havkin V. A. Al'ternativnye topliva: dostoinstva i nedostatki. Problemy primeneniya // Rossiyskiy Himicheskiy Zhurnal. 2003. Vol. 47, Issue 6. P. 4-11.

5. Bykova E. V., Gemonov A. V., Lebedev A. V. Perspektivy primeneniya toplivnogo etilovogo spirta na transporte // Vestnik FGOU VPO MGAU. 2014. Issue 3. P. 26-30.

6. Ethanol as fuel for recreational boats. URL: http://www.dartmouth.edu/ ethanolboat/Ethanol_Outboard_Final_Report.pdf

7. Vasilevkin E. V., Egorov V. N., Runovskiy K. S. Konstruktivnye izmeneniya v DVS, neobhodimye pri perekhode na benzoetanol'nye topliva // Izvestiya MGTU «MAMI». 2013. Vol. 1, Issue 1 (15). P. 10-14.

8. A study of the effects of running gasoline with $15 \%$ ethanol concentration in current production outboard four-stroke engines and conventional two-stroke outboard marine engines. National Renewable Energy Laboratory. URL: http://www.nrel.gov/docs/ fy12osti/52909.pdf

9. Azimov U., Tomita E., Kawahar N. Combustion and Exhaust Emission Characteristics of Diesel Micro-Pilot Ignited Dual-Fuel Engine // Diesel Engine - Combustion, Emissions and Condition Monitoring. 2013. doi: https://doi.org/10.5772/54613

10. Shudo $T$. Influence of gas composition on the combustion and efficiency of a homogeneous charge compression ignition engine system fuelled with methanol reformed gases // International Journal of Engine Research. 2008. Vol. 9, Issue 5. P. 399-408. doi: https://doi.org/10.1243/14680874jer01208

11. Maki D. F., Prabhakaran P. An experimental investigation on performance and emissions of a multi cylinder diesel engine fueled with hydrogen-diesel blends // Sustainable Transport. 2011. P. 3557-3564. doi: https://doi.org/10.3384/ecp110573557

12. Chatterjee A., Dutta S., Mandal B. K. Combustion performance and emission characteristics of hydrogen as an internal combustion engine fuel // Journal of Aeronautical and Automotive Engineering. 2014. Vol. 1, Issue 1. P. 1-6. 